\title{
Corrective Feedback in Second Language Classrooms
}

\author{
Leonardo Véliz C.*
}

\begin{abstract}
:
In this paper l attempt to analyse and survey the role of corrective feedback-more specifically recasts-in the interaction between teachers and $\mathrm{L} 2$ students in a classroom. Thus, I explore the effects of recasts on students' self-correction in order to finally come to the conclusion whether or not students are able to notice this type of underlying correction and, therefore, reformulate their ill-formed utterances. Besides, I also undertake a comprehensive survey of the literature on the topic. Two different groups of students from the English Teaching Trainig Programme at Universidad Católica Raúl Silva Henrríquez are studied. Five students taking English courses at an intermediate level and five taking advanced English courses. Intermediate and advanced students have been categorised on the basis of their number of English language courses they have taken. Intermediate students have taken four, whereas advanced have taken seven. In this paper the point at issue is whether harmful and ineffective or essential and rather effective, and whether recasts are noticeable for students to 'read between lines' and figure out the underlying correction. I take the stand that recasts are only effective when using them with advanced students as they are more cognitively advanced and, therefore, able to make inferences and interpret the implicit message to reformulate their mistakes. The results as well as the tests on the whole, clearly demonstrate that recasts as a corrective technique happen to be a bit more effective with advanced students than with intermediate students, though the difference is not striking.
\end{abstract}

Key words: Corrective feedback, recasts, clarification request, positive feedback, negative feedback

\section{Resumen:}

En el presente trabajo procuro analizar el rol de la asesoría remedial o retroalimentación correctiva, precisamente Recasts (corrección implícita), en la interacción entre profesores y alumnos de una segunda lengua. De esta manera, analizo los efectos de la corrección implícita en la auto-corrección de los alumnos para finalmente llegar a la siguiente conclusión: los alumnos avanzados son capaces de percibir este tipo de corrección implícita ya que sus habilidades cognitivas están más desarrolladas. Dos grupos de la Universidad RSH son estudiados. Cinco estudiantes pertenecientes a un nivel intermedio y cinco a nivel avanzado han sido categorizados de acuerdo al número de cursos tomados durante los semestres en la universidad. Mi planteamiento se relaciona a que la corrección implícita (recasts) serán sólo efectiva con estudiantes cognitivamente más avanzados ya que son capaces de hacer inferencias con mayor rapidez, auto-corregirse y así reformular las oraciones mal formuladas y estructuradas.

Palabras clave: retroalimentación correctiva, corrección implícita, pregunta de clarificación, retroalimentación positiva, retroalimentación negativa

* Universidad Católica Raúl Silva Henríquez. M. A. @ in Linguistics. Ivelizc@ucsh.cl 


\section{Introduction}

When we ask ourselves about what technique or method we use when teaching language, in our case English, the answer is complex and requires a long explanation. As a matter of fact, if we make an attempt to answer such a complex question we are forced to look back on our history of Language Teaching. Social and Linguistic Sciences, particularly the field of Language Teaching, have been subjected to various changes from the very beginning.

Teachers all over the world have gone through the same situation; adapting their methods and techniques to newer and more modern ways of presenting and teaching the language in their classrooms, and getting accustomed to newer approaches and newfangled perspectives which, in most cases, end up being very innovative and revolutionary at the same time.

From the Classical Method which dates back to the $17^{\text {th }}$ and $18^{\text {th }}$ century, and whose main premise was based on the learning of Latin and Greek, to those more modern ones, such as Strategies-Based Instruction, Communicative Language Teaching and even the so-called notion of "Eclectisism" have attracted many teachers and Language researchers' attention as to what premises, patterns and approaches to follow in order to make the teaching of language increasingly effective. Besides, all of the components and factors involved in language teaching have also suffered the consequences. Thus, the focus on the classrooms' contents, students' participation in the class, the aspect of language to be emphasised; whether accuracy or fluency, errors made by students, correction of errors on the part of the teacher and peers in general have also been a mater of study and analysis.

In this paper, my main purpose is to provide some crucial information regarding different types of corrective feedback and mention the notion 
of recasts and analyse its effects on second language learning by referring to how effective or ineffective they are.

\section{Competence vs. Performance}

This is one of the distinctions drawn by Chomsky (1965) when he analysed the Linguistic theory and made clear assumptions with what Linguistic Theory should be concerned. Competence, on the one hand, is related to psychological and mental properties of the mind; in other words, it refers to the abstract part of the language: The knowledge stored in the mind. (Chomsky:1965, p. 3)

On the other hand, Performance refers to the realization of the abstract part of the language in the actual production of utterances in a certain place and at a certain time which includes all the grammatical and non-grammatical features of language as well as the linguistic and nonlinguistic aspects of it, viz. contextual and situational factors, hesitations, slips of the tongue, body language, and so forth. (Chomsky: 1965)

It is also important to highlight the changes and perspectives the notion of performance has adopted. For instance, some researchers have put a great deal of emphasis on pragmatic aspects of the language and performance alike. Situational and contextual aspects are crucial when thinking of language in use or performance. Hymes (1972) put it very clearly when he introduced a somewhat different notion of performance, adding a few components to Chomsky's definition. Communicative competence, in contrast to Chomsky's definition, has taken the form of appropriateness of language to particular situations or contexts and its sociocultural significance, in other words it is the knowledge of how and when to use language appropriately. This definition seems to be more narrowed-down as language occurs among people and in context with all its situational components which affect and interrupt the flow of a conversation at times. In any Second Language classroom, performance, producing language orally, and communicative competence- knowing how, when and where to use an utterance appropriately- are two main goals to be achieved by language teachers. However, when it comes to producing language orally and using the language in communicative contexts teachers are faced with a very difficult problem to tackle, that of students' errors and how to treat them. 


\section{Corrective Feedback}

Error correction has always been a very controversial topic, and perhaps a thorny issue as there is very little agreement as to how to correct somebody who has made an error and whether this correction will be effective or not.

Error correction can easily be described on a continuum ranging from the idea that it can be harmful and ineffective to being very essential and beneficial for some grammatical structures.

According to recent studies, as will be shown later on, it has been proved that error correction is effective, necessary and essential but the obstacle which prevents error correction from being totally effective lies in teachers' inconsistency and unsystematic ways of dealing with errors. Whether systematic, consistent or effective the teacher's reaction is to errors, corrective feedback has been widely defined as:

“...The teacher's response to a student error"

(Dekeyser: 1993)

\subsection{Different types of feedback}

While second language acquisition researches (SLA) have agreed that input is essential and important in second language acquisition, many others still debate the form that input should take, either positive or negative.

\subsubsection{Positive feedback vs. Negative feedback}

Positive feedback, on the one hand, is regarded as important and crucial for adult second language acquisition (krashen: 1977, 1994) whereas, on the other, some other researches have considered it to be insufficient for second language learning.

Apart from its importance and sufficiency, positive feedback plays a role in language learning and it refers to those elements and type of evidence given to learners which tell them what is possible in the $T L$, as opposed to negative feedback which is related to the type of information given to learners that tell them what is not possible in the $T L$, being the former more descriptive; whereas the latter is more prescriptive as it tells the learner what $s /$ he is not allowed to say because the target language structure does not allow it.

Negative feedback is divided into two other types: Preemtive and reactive. The former tries to prevent learners from making mistakes by 
giving clear instructions and explanations together with explicit grammar rules. The latter takes place after the mistake has been made by the learner. This reaction to error making can be implicit or explicit on the part of the language instructor, i.e. the way the language teacher corrects the mistake can be very explicit by telling the student that the sentence $\mathrm{s} / \mathrm{he}$ has produced is wrong because of this and that reason. But it can also be an implicit way of correcting the mistake by repeating the ill-formed utterance, by using clarification requests, such as Pardon? Sorry?

Recasts fall into the implicit category of corrective feedback.

\section{Are recasts really effective?}

As suggested before, negative feedback can also include implicit indications that an utterance is not well formed. Recasts, for instance, make a complete reformulation of a learner's ill-formed utterance and provide relevant information which is obligatory but is either missing or wrongly used in the learner's utterance. E.g. My dad works from Monday to Friday, as a recast of "My dad work from Monday to Friday").

Even though recasts are the most frequent type of corrective feedback used by language instructors, it has been proved that they are not completely effective in the classroom, that is, recasts have resulted in uptake much less frequently than any other type of feedback.

By uptake we understand the learner's response to the teacher correction and, at the same time, the attempt made by the learner to reformulate $\mathrm{h} / \mathrm{his}$ ill-formed utterance and produce the correct one.

\section{The study}

The data collected has been obtained from a series of four audio-taped lessons with both intermediate and advanced students. The lessons audio-taped were focused on oral activities for students to practise for an oral test they would have. The main structural contents to be covered with the intermediate class were as follows:

(i) Past simple vs. Past continuous

(ii) Past simple and past perfect

(iii) Prepositions (in - on - at)

On the other hand, the advanced class was focused on the following contents: 
(i) Conditionals (If-clauses)

(ii) Modal auxiliary verbs and semi-auxiliary verbs (can - could -will -be supposed to-be about to - be meant to).

(iii) Phrasal verbs (some with -up and -down)

All of the oral conversations occurred during normal and ordinary grammar lessons at university.

\subsection{Some extracts from conversations}

\section{Intermediate class:}

One of the questions the teacher asks one of the students to elicit information on past simple and continuous is:

Teacher: Tell me Pamela about some of the things you did at the weekend (the class was on a Monday).

Pamela: Well, mmm... the Saturday I get up a bit more later than usual because is the only day I can to rest more.

Teacher: D'you know what I did on Saturday? On Saturday my wife and I went to the supermarket early in the morning and got back home at about eleven. So, when did you get up a bit later? On Saturday or Sunday?.

Pamela: On the Saturday, I.....get... a bit more later.

In this short dialogue, we can see that the student, Pamela, has made a lot of mistakes concerning the use of prepositions and comparative forms. When the teacher interacts with the student reformulating the wrongly-used article in the Saturday instead of the preposition, the student is able to -unconsciously I believe- grasp part of the correction in the form of recasts but continues using the definite article and saying on the Saturday.

Intermediate class: (another part of the conversation, now using clarification requests as correction)

Teacher: So, Roberto. Your girlfriend was not in when you phoned her yesterday morning?

Student: Mmm.. No, She wasn't in the house. She has already come to the university when I phone her. 
Teacher: Sorry? What did you say? Could you say it again please, Roberto?

Student:... That she was not in the house when I phoned. She already had come to the university.

Teacher: Oh, right. She had already come to university when you phoned her (very slowly).

Student: Yeap. She...

In this part of the conversation, we clearly see that the clarification request used by the teacher as a type of corrective feedback reformulated part of the ill-formed structure used by the student in the sense that the student was able to comprehend, on the one hand, that there was an underlying message when saying: Sorry? Say that again please? He realised he was making a mistake. On the other hand, the student did his best to correct his own mistake but does it in such a way that syntactically in not perfect, that is, he changes the position and order of some of the units; but despite the wrong position of some of the units, he is able to understand and reformulate the tense and aspect he was using. He had previously used a present perfect structure, but then he changed to past perfect, which was the tense and aspect the teacher was expecting.

\section{Advanced class:}

In this class, the teacher and the students are expected to go through some more advanced topical and grammatical contents, such as If-clauses and phrasal verbs.

(In the middle of a conversation between the teacher and Roxana, who are using (f-clauses in context).

Context: The teacher asks her what she would do if knew that she has a test as soon as she walks in to the classroom.

Roxana: ... I think I would talk to the teacher to ask her for the permission to give the test other day.

Teacher: what exactly would say to the teacher? (trying to elicit more information and sentences in the conditional form)

Student: ...Mmmm (a lot of hesitation) ... don't know. I would... I will talk and say "Teacher I can't give the test 'cause I don't feel prepared"...

(and the student goes on and on) 
In this small piece of conversation, we can see a shift in the usage of the conditional on the part of the student. This shift, from would to will, is mainly because of the pressure the student is feeling at that moment as she knows how to use the conditional form right after a question, but when it comes to giving reasons, arguments and expand a bit the more the answer she is giving, she faces difficulties. This is a good strategy we as teachers should use in order to really confirm the understanding of a patter, rule, lexical item and so forth. Students normally learn a lexical item, a grammatical structure in one context only, but when the teacher reformulates or changes the context just a little bit, the student feels a bit puzzled and shocked as s/he thinks it is a totally different thing. In other words, we should decontextualise language at some stages and play with it, create new things, make up new phrases, invent new collocations and come up with new metaphors in such a way the students feel that language is not something that has to be understood in one context and not in the other.

\section{Advanced class: (another part of a different conversation)}

In the middle of a conversation...

Teacher: ...everybody has different kinds of responsibilities. People at work are supposed to be on time, we are supposed to show respect to everybody... what else are we supposed to do Javier?

Javier: ...Mmm.... well, we like students are supposed that we study for a test..

Teacher's interruption: ... I guess you are not supposed to study only for a test, you are supposed to study for life, aren't you?

Javier: yeap, sorry I know... so..we are supposed to study for life, and also we are supposed that we are friendly with teachers and our classmates.

Teacher: ..and we $\underline{\text { AS }}$ (VERY EXPLICIT) teachers are supposed to be friendly with students as well.

Javier: yeap, all of us as students are supposed to be kind and nice with everybody.

Teacher: Very good, Javier, Excellent. You are right. You AS STUDENTS ARE SUPPOSED TO BE KIND AND NICE TO EVERYBODY.

In this piece of conversation we clearly see that the student is not able to grasp the structure of the semi-auxiliary verb despite the various 
examples given by the teacher before giving the students the opportunity to talk. However, when the student has the chance to talk, he keeps using a that-clause instead of the verb in infinitive. But at some point in the conversation he manages to use the form correctly but soon afterwards he goes back to the old ill-formed structure. But, at the end of the conversation Javier managed to understand and grasp the correct form jus out of the interaction between the teacher and himself.

In order to try to account fro the above-mentioned kind of mistake, we can say that this is due to the interference of $L 1$, as we certainly use a that-clause in Spanish when using a semi-auxiliary verb like be supposed to. As for the difference between as and like, it is something we need to tackle in the classroom with a large number of exercises of different kinds in order for them to comprehend and internalise the different contextual uses of as and like.

\section{Results}

Regarding the results and analyses of all the conversations audiotaped (4 different conversations to be precise), one of the conclusions I have arrived at is that despite recasts are the most widely-used type of corrective feedback in the classroom, they tend to be rather ineffective as, most of the time, students do not even realise $\mathrm{s} / \mathrm{he}$ is being corrected implicitly, they simply believe the teacher is jus interacting with them. Nevertheless, I have found that students who are a bit more cognitively advanced - and consequently more capable of sorting out underlying meanings and messages- are able to perceive the correction in the form of recasts as they know more about English and most of them want to sound native-like and grammatically close to a native speaker so they are more aware of the mistakes they make and, therefore, their corresponding correction.

The following chart shows us the type of correction which was used by the teacher and how students responded to such corrections. The percentages used in the chart show the number of uptakes on the part of the students. In other words, they show the number of times students reformulated their ill-formed utterance correctly.

\begin{tabular}{|l|c|c|c|}
\hline Feedback type & Recast & Explicit correction & clarification request \\
\hline Intermediate & $\mathbf{2 5 \%}$ & $\mathbf{5 2} \%$ & $\mathbf{2 3} \%$ \\
\hline Advanced & $\mathbf{3 8 , 5} \%$ & $\mathbf{5 \%}$ & $\mathbf{5 6 , 5 \%}$ \\
\hline & uptake\% & uptake $\%$ & uptake $\%$ \\
\hline
\end{tabular}




\section{Conclusions}

As Language Teaching Methods have changed and progressed over time, the role of corrective feedback has also made remarkable progress in the last two decades, particularly in the 90 's.

Concerning the inconsistency and effectiveness of recasts and corrective feedback in general, it has come to be known that problems regarding the inconsistency and ambiguity are due to the lack and unsystematic approaches adopted by the majority of teachers as far as correction is concerned. Thus, in order for corrective feedback to be very effective teachers need to more consistent and systematic when correcting faulty utterances because it has been found that teachers sometimes accept ill-formed utterances and some other times they do not.

\section{References}

Chomsky, N. (1965). Reflections on language. New York: Pantheon.

Dekeyser, R. (1993). "The effect of error correction on L2 grammar knowledge and oral proficiency". Modern Language Journal,77, 501-514.

Hymes, D. (1972). $\quad$ On communicative competence. In J. B. Pride \& Holmes (Eds.), Sociolinguistics (pp.269-293).

Kelly, J. \& Stoops, L. (2000). Second and Foreign Language Learning Through Classroom Interaction. New Jersey: Lawrence Erlbaum Associates.

Krashen, S.D. (1994). Bilingual education and second language acquisition theory.

In bilingual Education Office (ed.) Schooling and language-minority students: A theoretical framework ( $2^{\text {nd }}$ ed., pp. 47-75). Los Angeles: Evaluation Dissemination and Assessment Center, California State University.

Sullivan, P. (2000). Spoken Artistry: Performance in a Foreign Language Classroom. In Second and Foreign Language Learning Through Classroom

Interaction, Kelly, J.\& Stoops, L.New Jersey: Lawrence Erlbaum Associates. 